\title{
Activation of AMPK under Hypoxia: Many Roads Leading to Rome
}

\author{
Franziska Dengler $(\mathbb{D}$ \\ Institute of Veterinary Physiology, University of Leipzig, D-04103 Leipzig, Germany; \\ dengler@vetmed.uni-leipzig.de; Tel.: +49-341-97-38-073
}

Received: 5 March 2020; Accepted: 30 March 2020; Published: 31 March 2020

\begin{abstract}
AMP-activated protein kinase (AMPK) is known as a pivotal cellular energy sensor, mediating the adaptation to low energy levels by deactivating anabolic processes and activating catabolic processes in order to restore the cellular ATP supply when the cellular AMP/ATP ratio is increased. Besides this well-known role, it has also been shown to exert protective effects under hypoxia. While an insufficient supply with oxygen might easily deplete cellular energy levels, i.e., ATP concentration, manifold other mechanisms have been suggested and are heavily disputed regarding the activation of AMPK under hypoxia independently from cellular AMP concentrations. However, an activation of AMPK preceding energy depletion could induce a timely adaptation reaction preventing more serious damage. A connection between AMPK and the master regulator of hypoxic adaptation via gene transcription, hypoxia-inducible factor (HIF), has also been taken into account, orchestrating their concerted protective action. This review will summarize the current knowledge on mechanisms of AMPK activation under hypoxia and its interrelationship with HIF.
\end{abstract}

Keywords: AMPK; $\left[\mathrm{Ca}^{2+}{ }_{\mathrm{i}}\right.$ ]; CaMKK; FIH1; HIF; HIF-P4H; hypoxia; LKB1; reactive oxygen species (ROS)

\section{Introduction}

The AMP-activated protein kinase (AMPK) is a well-known energy sensor, not only in mammalian cells, but has been shown to be an ancient mechanism that has been conserved throughout the evolution of complex life [1-3]. In the last decades its upstream and downstream regulatory mechanisms have been characterized [2], and therapeutic implications of its activation and inhibition, respectively, are beyond speculation $[4,5]$. However, besides its classical role as an energy sensor, not all aspects of its biological function have yet been completely unraveled.

Hypoxia, i.e., an inadequate oxygen supply compared to the cellular demand, occurs not only in pathological situations like ischemic stroke or myocardial ischemia, but is a common feature under inflammatory conditions and also perceived in healthy organs depending on their current perfusion rate [6]. Thus, there seem to be adaptation mechanisms to hypoxia in order to secure cellular survival under these conditions.

An activation of AMPK under hypoxia has been reported repeatedly while the mechanism of this activation and its biological relevance are under discussion. This review will focus on summarizing the current knowledge regarding the role and activation of AMPK under hypoxia.

\section{General Characteristics of AMPK}

The serine/threonine kinase AMPK is composed of three subunits $(\alpha, \beta$ and $\gamma)$ [7]. Each of these subunits comprises several isoforms (so far $\alpha 1, \alpha 2, \beta 1, \beta 2, \gamma 1, \gamma 2, \gamma 3$ ); thus, a total of at least 12 combinations and thus isoenzymes are possible. These isoenzymes seem to have different 
tissue distributions and also specific functions, which are just in the early stages of classification [8]. However, all heterotrimers are basically activated by phosphorylation of a threonine residue within the catalytic $\alpha$ subunit [3,7]. This residue is conformally called "Thr172", according to its position in the human sequence, although it might vary between species. Besides this phosphorylation, two other mechanisms enhance AMPK activation. Binding of AMP (and to a lesser extent also ADP) to the regulatory $\gamma$ subunit leads to i) an allosteric activation supporting phosphorylation at the $\alpha$ subunit and ii) prevents the dephosphorylation of Thr172 [2], thus coupling its activity tightly to cellular energy levels. The phosphorylation at Thr172 is mediated by at least two upstream kinases. The first to be identified was liver kinase B1 (LKB1) [1,9], while identification of $\mathrm{Ca}^{2+} /$ calmodulin-dependent protein kinase (CaMKK) 2, also known as $\beta$, as another upstream kinase followed soon after [10-12]. There are hints that they might even exert different isoform-specific effects on AMPK [13]. There might still be other kinases that activate AMPK but are not characterized yet [14]. Thus, transforming growth factor- $\beta$-activated kinase 1 (TAK1) might also phosphorylate AMPK at Thr172 under specific conditions like inflammation $[15,16]$.

The activation of AMPK has mainly been reported to be initiated by an increased AMP/ATP ratio, i.e., when cellular energy levels drop due to cellular stresses like glucose deprivation, inhibition of mitochondrial oxidative phosphorylation or toxic agents [3,17]. Then, it acts on both gene expression and protein levels to adapt the cellular metabolism by deactivating energy consuming, anabolic processes and activating processes that deliver "cheap" energy such as glycolysis [2,18]. AMPK has also been shown to be a major promotor of mitochondrial biogenesis, thus enhancing cellular capability to provide energy substrates [19]. So far, more than 60 targets of AMPK have been identified [3]. Numerous extensive reviews on the targets and characteristics of AMPK can be found [20-22], while this review will focus on the role of AMPK activation under hypoxia.

\section{Definition of Hypoxia}

Hypoxia is defined as a condition in which the cellular oxygen supply is reduced so that it does not meet the cellular oxygen requirements [23]. Due to variations in tissue perfusion, oxygen levels may change throughout the day and with the functional status of the tissue, whereas more oxygen-sensitive tissues like the brain or the heart need a constantly high oxygen supply and quickly suffer from oxygen deprivation (e.g., an ischemic stroke) [24]. This disease pattern infers another problem: due to its origin in a lack of perfusion, hypoxia is often accompanied by a lack of nutrients as well, termed ischemia. Therefore, it is hard to judge mechanisms initiated by hypoxia independently from the cellular energy status.

However, hypoxia is not always associated with severe pathologies like ischemic stroke or myocardial infarction, but it also occurs under inflammatory conditions [6] and within the physiological range of the cells' adaptation capacities, being referred to as "physiological hypoxia" [23]. The intestinal epithelium gives a great example of this circumstance because of its location as the borderline between the anaerobic gut lumen and the organism, which renders its oxygen supply to the blood vessels only at the basal cell pole. Additionally, this perfusion underlies large variations reflecting the digestive activity and thus usually leaves the enterocytes with a mere $2-4 \%$ oxygen level [25]. Still, these cells function well with this varying perfusion, implicating that they are equipped with effective adaptation mechanisms to survive under hypoxia. AMPK might play a central role in mediating this adaptation.

\section{The Role of AMPK under Hypoxia}

It is intriguing that saving energy is an important rescue factor in cells undergoing hypoxia. Therefore, a role of AMPK in hypoxic adaptation seems logical. Indeed, there has been increasing evidence of activation of AMPK acting protectively in hypoxia-associated pathologies, e.g., ischemic injury in heart, brain or guts [26-29]. By decreasing the cellular ATP consumption, the oxygen demand is also lowered; thus, cellular survival is enhanced [30,31]. 
An activation of AMPK under hypoxia has been demonstrated in various tissues and cell types, ranging from brain [32-34], liver [35] and skeletal muscle [36-38] to cardiomyocytes [39,40], alveolar epithelial cells [41,42], intestinal epithelial cells [43,44] and fibroblasts [45]. Interestingly, an inhibition of AMPK activation under hypoxia was reported after long-term hypoxia (in this case $8 \%$ oxygen for $12 \mathrm{~d}$ ) [46]. However, in the latter study mice were not only kept under hypoxia for a long period but also fasted $24 \mathrm{~h}$ after that, which might explain discrepancies to other studies. Older mice have also been reported to have a blunted response of AMPK to hypoxia, which might be explained by already constitutively increased levels of AMPK activation in comparison to younger animals [35]. In contrast, a suppression of AMPK activity was observed under hyperoxia [47], forming the counterpart to hypoxia-mediated activation.

An important mechanism to secure cellular survival under hypoxia is autophagy [48], which has been demonstrated to be initiated by AMPK in various cell types [49-52]. This further strengthens the assumption that AMPK plays a major role in the adaptation to hypoxic stress. Although a few studies also observed AMPK-independent initiation of autophagy under hypoxia $[53,54]$, nowadays AMPK is well accepted as a crucial factor for cellular survival during and in recovery after hypoxic insults. The mode of its action and activation, though, is not yet as clear. With respect to the coupling of hypoxia to metabolism, the increased cellular AMP levels induced by hypoxia may be considered the only pathway inducing the activation of AMPK under hypoxia. However, an activation of the adaptation mechanisms even before the cells enter the actual emergency would be desirable. Thus, a lot of research has been conducted aiming to identify other mechanisms activating AMPK under hypoxia. In the following, the current knowledge on the activation of AMPK with special consideration of hypoxia will be summarized.

\section{Activation of AMPK under Hypoxia}

While activation of AMPK under hypoxia has often been shown, it is still under discussion whether this activation is mediated by the hypoxic stimulus specifically $[55,56]$ or if it is a side effect of the metabolic (and thus energetic) consequences inferred by hypoxia [47,57]. Also, if the former was true, how is the activation of AMPK mediated under hypoxia?

It is beyond doubt that the upstream kinases LKB1 and CaMKK2 play a central role in phosphorylating and thus activating AMPK [58]. Still, their activation has to be initiated, and there may additionally be other pathways independent of the upstream kinases $[59,60]$. Besides the canonical pathway via an increased AMP/ATP ratio with subsequent activation of LKB1, there is proof of a $\mathrm{Ca}^{2+}$-dependent activation of AMPK by CAMKK2 under hypoxia. Many studies claim that an increased production of reactive oxygen species (ROS) under hypoxia leads to an activation of AMPK, while hypoxia-inducible factor (HIF)-hydroxylase enzymes have been supposed to play a role in the regulation of AMPK, but there is little proof. Finally, several hormones and systemic glucose levels seem to play a role as well. In the following, the mechanisms proposed and investigated so far will be presented. They are summarized in Figure 1. 


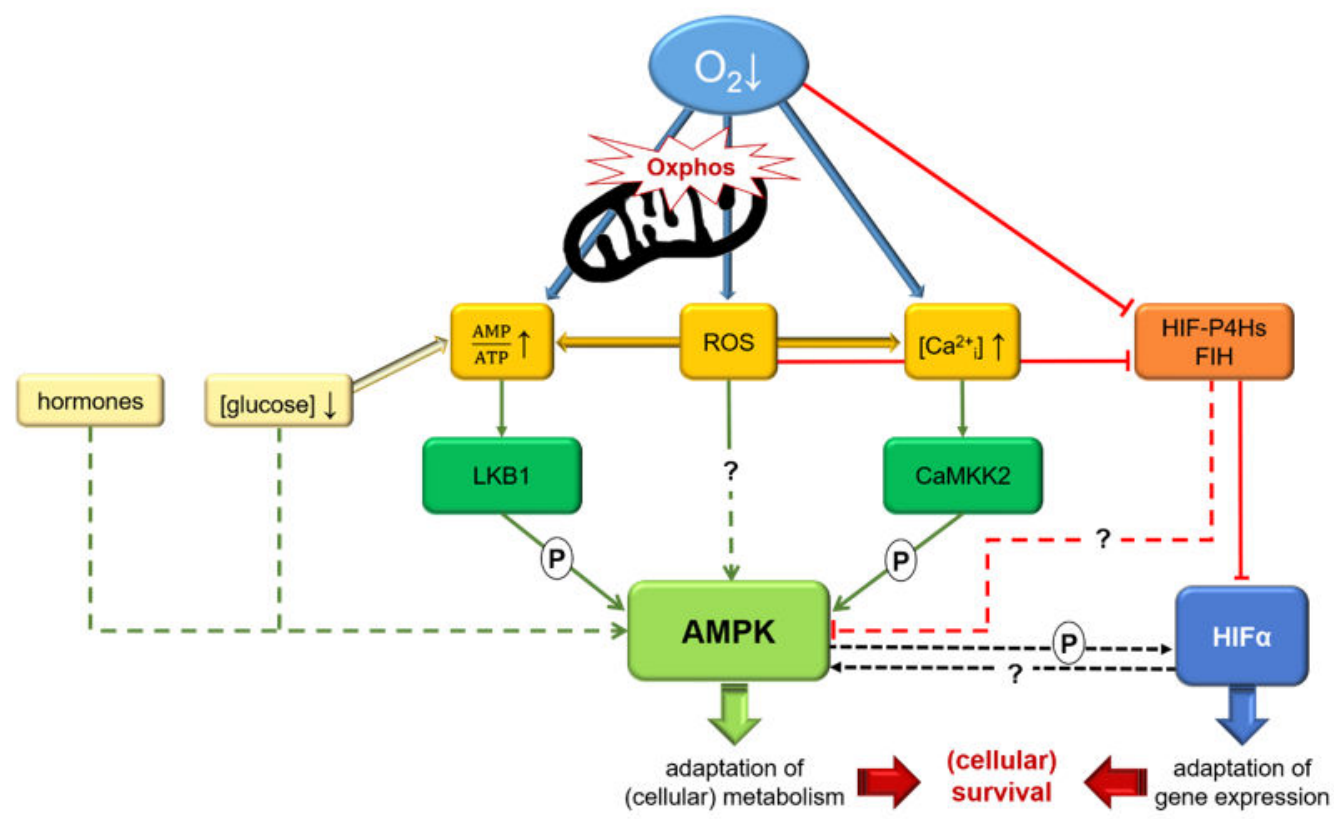

Figure 1. Graphical summary illustrating possible mechanisms regulating AMP-activated protein kinase (AMPK) activity under hypoxia. A decreased oxygen supply impairs oxidative phosphorylation (oxphos) in mitochondria and thus leads to increased AMP/ATP ratios, which will activate the canonical pathway of AMPK activation by LKB1. Besides LKB1, AMPK can also be phosphorylated by CaMKK2 subsequently to an increase of $\left[\mathrm{Ca}^{2+}{ }_{\mathrm{i}}\right]$ under hypoxia. Impaired mitochondrial oxphos also causes formation of reactive oxygen species (ROS), which might not only induce these pathways but also activate AMPK directly. ROS are also supposed to inhibit hypoxia-inducible factor (HIF)-hydroxylase enzymes, which work oxygen-dependently and have been suggested to regulate AMPK in concert with HIF. Crosstalk between AMPK and HIF might help to orchestrate the adaptation to low oxygen levels as well. More details are given in the text.

\section{1. $A M P$}

The canonical way of activating AMPK via an increased AMP/ATP ratio has been demonstrated under hypoxic conditions [42,61]. This makes sense, as a depletion of oxygen would always lead to a restrained metabolism, especially mitochondrial oxidative phosphorylation, resulting in low cellular energy levels. An AMP-dependent activation of AMPK was reported in lung epithelial cells under hypoxia [42] and in kidney epithelial cells under ischemia [27] as well as in murine heart muscle [62]. Specialized oxygen-sensing cells in the carotid body seem to react to an increased AMP/ATP ratio as well [63], indicating that AMPK is not only guarding cellular but also systemic oxygen levels.

However, there have also been many reports of an activation of AMPK without any observable changes in AMP concentrations [41,59,64]. It would be advantageous if the cellular adaptation machinery was activated even before the actual damage happens. In contrast to that, Wilson et al. argue that total AMP concentration, which is usually measured in cultured cells, does not equal free (and more relevant in terms of energy supply) AMP concentration, which might therefore be underestimated in many studies [47]. There is evidence that the different isoforms of the AMPK subunits display different sensitivities to AMP and might thus react to different stimuli [8] and imply different sensitivities according to their tissue distribution.

\subsection{LKB1 versus CaMKK2}

It has been shown that activation of AMPK via increased AMP/ATP ratios primarily implies activation via LKB1. This conclusion is suggested by studies in mice with a hypomorphic expression of LKB1, which abrogated AMPK activation under hypoxia in smooth muscle cells, while a knockout 
of CaMKK2 had no effect on the activation of AMPK under hypoxia in mice [57]. In lung epithelial cells, only inhibition of LKB1, but no other upstream kinase, abrogated the activation of AMPK under hypoxia [42].

In contrast, CaMKK2 seemed to be responsible for AMPK activation under hypoxia in alveolar epithelial cells [39]. This might be explained by different abundances of the upstream kinases in these cell types [42], but also by differing specificities for the AMPK subunit isoforms. Thus, LKB1 seems to activate only the $\alpha 2$ but not $\alpha 1$ subunit in muscle cells [13,62]. However, an activation of both subunits was observed under hypoxia in the heart muscle of mice, and the $\alpha 1$ subunit was phosphorylated in LKB1-deficient cells as well [62], indicating that another upstream kinase besides LKB1 activates AMPK under hypoxia; CaMKK2 being the natural candidate.

\subsection{CaMKK2 and Intracellular $\left[\mathrm{Ca}^{2+}\right]$}

Several groups report a connection of AMPK activation under hypoxia and $\left[\mathrm{Ca}^{2+}{ }_{\mathrm{i}}\right][32,65,66]$. The most obvious explanation would be a $\mathrm{Ca}^{2+}$-dependent activation of the upstream kinase CaMKK2. This was shown in both HeLa and HEK293T cells where AMPK was activated under hypoxia concurrently with an increase of $\left[\mathrm{Ca}^{2+}{ }_{\mathrm{i}}\right]$ and inhibited by incubation with the CaMKK2 inhibitor STO-609 [67]. It was demonstrated in alveolar epithelial cells (in contrast to lung epithelial cells, see above) that, subsequently to hypoxia, an increase in $\left[\mathrm{Ca}^{2+}{ }_{\mathrm{i}}\right]$ led to a CaMKK2-dependent activation of AMPK [42]. Thus, the regulation of AMPK activity under hypoxia might differ tissue-dependently.

\subsection{Reactive Oxygen Species}

$\mathrm{H}_{2} \mathrm{O}_{2}, \mathrm{O}_{2}{ }^{-}$and $\mathrm{HO}$ are summarized under the term ROS [68,69]. While the single members of this group vary greatly in their roles and effects, all of them act as intracellular messengers both in microorganisms and in mammals [68,70]. There are ambivalent reports on the formation of ROS under hypoxia: while the production of ROS might be reduced in order to avoid cellular damage, it could also be increased as part of the oxygen-sensitive signaling system mediating the adaptation reaction [69]. These contradicting findings may be due to diverse model systems used and are discussed in recent reviews $[69,70]$.

It has been demonstrated, though, that ROS formation is accompanied by an activation of AMPK $[60,71,72]$ and that the ROS are generated by mitochondrial complex III under hypoxia $[70,71]$. This ROS-dependent activation was abrogated by the additional incubation with ROS scavengers [55]. In contrast, Tan et al. could not confirm any effect of the scavengers on activation of AMPK under hypoxia, e.g., in airway epithelial cells [42].

Additionally, the reports vary in the means by which this ROS-dependent activation of AMPK is supposed to work. Due to the harmful accumulation of ROS, the AMP/ATP ratio could be increased, thus leading to an activation of AMPK [73,74], whereas others report the AMP concentration to be unchanged after hypoxia-induced ROS formation and AMPK activation [41,55,60,71]. Still, there are different theories on AMP-independent mechanisms downstream of ROS: Zmijewski et al. [60] propose the oxidation of a cysteine residue in the AMPK $\alpha$ subunit by $\mathrm{H}_{2} \mathrm{O}_{2}$, leading to its activation, partly by autophosphorylation; Emerling et al. [71] demonstrate that the ROS-dependent activation of AMPK is necessarily mediated by LKB1 and might be seconded to a small part by CaMKK2; and last but not least, Mungai et al. [55] and Gusarova et al. [41,75] find a coupling to $\left[\mathrm{Ca}^{2+}{ }_{\mathrm{i}}\right]$, which would then activate AMPK via CaMKK2.

Besides ROS, also $\mathrm{CO}_{2}$ [76] and $\mathrm{CO}$ [66] seem to induce an activation of AMPK in alveolar epithelial cells and astrocytes.

However, AMPK seems to be involved in cellular redox signaling in both directions, which is mirrored by its influence on mitochondrial biogenesis, the site of both production and elimination of ROS [19,77]. Thus, an activation of AMPK has been shown to stabilize cellular ROS production below a toxic threshold [77]. Additionally, there seems to be a functional triangle between AMPK, the mammalian target of rapamycin complex (mTORC) 1 and thioredoxin-interacting protein (TXNIP) in 
a way that AMPK controls autophagy and excessive production of ROS mediated by mTORC1 and TXNIP [78]. The involvement of AMPK in cellular redox homeostasis has been reviewed extensively elsewhere [77].

\subsection{HIF-hydroxylase Enzymes}

Being subject of the latest Nobel Prize in Physiology or Medicine, the hypoxia-inducible factor (HIF) is well known as the master regulator of gene transcription under hypoxia $[79,80]$. Its regulation by hydroxylase enzymes has been thoroughly characterized by the Nobel laureates (extensively reviewed in [81]) and is mainly mediated by hydroxylation at proline residues by the HIF-prolyl-4-hydroxylases (HIF-P4Hs) and additionally by asparaginyl hydroxylation by another hydroxylase termed factor inhibiting HIF1 $\alpha$ (FIH1) [82]. So far, the HIF-P4Hs occur in four isoforms (HIF-P4H 1, 2, 3 and transmembrane). This oxygen-dependent hydroxylation leads to the degradation of the HIF $\alpha$ subunit in the cytoplasm, thus preventing its translocation into the nucleus where it would dimerize with the $\beta$ subunit and lead to the transcription of $>300$ genes mediating cellular adaptation to hypoxia. Under hypoxia, the hydroxylation is hampered due to the lack of the cofactor oxygen, and the translocation and thus transcription is initiated [83].

Therefore, it would be convenient if AMPK was regulated by the same hydroxylation mechanisms under hypoxia, orchestrating a common adaptation reaction. Indeed, we could previously show an activation of AMPK in CaCo-2 cells both under hypoxia and upon treatment with the pan-hydroxylase inhibitor dimethyloxalylglycine (DMOG) [44]. In line, Yan et al. [84] were able to induce an activation of AMPK in cardiomyocytes by application of DMOG or siRNA for HIF-P4H 2. This activation was dependent on $\left[\mathrm{Ca}^{2+}{ }_{\mathrm{i}}\right]$ and CaMKK (see above), but not on LKB1 [84]. Thus, the authors propose a coupling of HIF-P4Hs and $\left[\mathrm{Ca}^{2+}{ }_{\mathrm{i}}\right]$, leading to an activation of AMPK under hypoxia [84].

In contrast, a group of renowned researchers recently reported that they could not confirm any other speculated hydroxylation targets of the HIF-P4Hs than HIF, casting the role of HIF-P4Hs in the regulation of AMPK into doubt [85]. FIH1, though, has a more accessible catalytic site and, unlike the HIF-P4Hs, does not undergo major conformational changes upon substrate binding and may thus be less substrate-specific [85]. Activation of AMPK by FIH1 has already been described in brown adipose tissue [56], although proof of an actual hydroxylation of AMPK is still lacking. Scholz et al. [86] suggest an indirect action of FIH1 on AMPK activity via the deubiquitinase OTUB1 in human embryonic kidney cells.

\subsection{Hormones and Other Mediators}

The protective effects of AMPK have been considered in the context of several hormones that might be associated with (systemic) energy depletion or inflammatory stimuli. The "hunger hormone" ghrelin has been considered to be protective in ischemia/reperfusion injury and has been shown to activate AMPK $[87,88]$, probably via CaMKK2 [89]. Also, leptin signaling, which basically acts antagonistic to ghrelin, has been reported to activate AMPK in chronic intermittent hypoxia independently of AMP levels in peripheral tissues like skeletal muscle $[13,64,90]$, whereas it exerts an inhibitory effect on hypothalamic AMPK [91,92]. This could be interpreted as another sign of the tissue-specific roles of AMPK, controlling both local and systemic energy levels. The systemic metabolic signaling might not be connected directly with hypoxia, though, but rather considered as an effect of a general metabolic switch that is most probably started by energetic imbalances.

Besides this more "obvious" connection, there have also been reports about the coagulation enzyme thrombin and its antagonist antithrombin to act protectively under hypoxia via activation of AMPK $[59,93]$. With respect to thrombin, this seems to be mediated via G-protein coupled receptors leading to an increase of $\left[\mathrm{Ca}^{2+}{ }_{i}\right]$ and thus an activation of CaMKK2 [59], whereas antithrombin seems to apply an inflammatory signaling pathway [93]. 


\subsection{Glucose and Coupling to mTORC1}

Another non-canonical way of activating AMPK is glucose-sensing by a mechanism that was termed the "lysosomal pathway" [22,94]. Although not directly connected to hypoxia, it is still worth mentioning because an impaired perfusion infers not only a lack of oxygen but also glucose (i.e., ischemia). As a lack of glucose might also quickly result in an increased AMP/ATP ratio, it is all the more interesting that there also seem to be cellular mechanisms anticipating a lack of glucose even before it might become a problem in terms of energy levels.

Thus, aldolase has been proposed as a link between the availability of substrates and the activation of AMPK by an aldolase-vATPase-Ragulator complex at the lysosomal membrane, which will additionally bind AXIN-LKB1 and then activate AMPK at low cellular glucose concentrations [40,94,95]. At high glucose concentrations, this aldolase-vATPase-Ragulator complex is associated with the activation of mTORC1. Thus, the lysosomal pathway seems to be a converging point of AMPK and mTORC1, that have long ago been shown to act antagonistic, for example, in terms of autophagy, oxidative phosphorylation (and thus generation of ROS) and protein anabolism [96]. While an inhibition of the mTOR pathway by AMPK has been described before [97], this spatial connection has only been discovered recently $[40,94]$ and might also imply a fine-tuned coordination of these pathways. With respect to the role both mechanisms play in the cellular adaptation to hypoxia [98], this coordination could also be beneficial under hypoxic conditions.

\section{Crosstalk between AMPK and HIF}

Due to their common protective role under hypoxia, crosstalk between AMPK and HIF has often been suggested. An interrelated regulation of both mediators could help to orchestrate their concerted adaptation reaction. It has been reported that AMPK regulates transport mechanisms on the protein level, which are also targets for HIF1 on the transcriptional level, e.g., $\mathrm{Na}^{+} / \mathrm{K}^{+}$-ATPase, facilitated glucose transporters (GLUT) or $\mathrm{Na}^{+}$-coupled glucose transporter (SGLT1) and thus protects the cells from hypoxic damage $[38,42,44,99]$.

As already mentioned above (Section 5.5), the HIF-P4Hs were suggested as a common regulation mechanism coupling both pathways under hypoxia. However, definitive proof for an activation of AMPK via HIF-P4Hs remains elusive. Nevertheless, many studies identified the formation of ROS under hypoxia as the starting point for an inhibition of the HIF-P4Hs and a subsequent activation of HIF [71,100-102], while AMPK could be activated via subsequent increase in $\left[\mathrm{Ca}^{2+}{ }_{\mathrm{i}}\right]$ and CaMKK2 (see Section 5.4.) [103]. Sallé-Lefort et al. [67] even showed an effect of CaMKK2 inhibition on HIF1 $\alpha$ stabilization under hypoxia, which might imply a direct regulation of HIF1 $\alpha$ via CaMKK2 or AMPK.

Besides, there are also other hints at a direct regulation of HIF1 by AMPK and vice versa. After inhibition or knockout of AMPK, the activation of HIF1 was blunted under hypoxia or even when the HIF-P4Hs were inhibited [103,104]. It has been reported before that phosphorylation of HIF1 $\alpha$ was necessary for its transcriptional activity $[105,106]$, and as a protein kinase, this would be the most obvious effect AMPK could have on HIF1 $\alpha$. This phosphorylation could either happen directly at HIF1 $\alpha$ [100] or at upstream factors [104], regulating their inhibitory effects on HIF1 $\alpha$, e.g., by inhibiting hydroxylation of HIF [104].

In contrast, other studies report no crosstalk between AMPK and HIF, although their targets are redundant [5]. In either AMPK or HIF1 $\alpha$ knockout cells, an independent activation of each was demonstrated, ruling out a direct activation of one by the other $[107,108]$. There are even studies indicating antagonistic regulation mechanisms, showing an upregulation of HIF1 $\alpha$ when AMPK activity is reduced, at least in cancer cells [109-111]. This might be mediated by AMPK promoting HIF-P4H activity [112]. This fits well with the observation of AMPK ensuring high $\alpha$-ketoglutarate levels, which is an important cofactor for the HIF-P4Hs [22].

The fact that this antagonistic regulation has mostly been observed in cancer cells so far draws attention to the roles AMPK and HIF1 are supposed to play in tumorigenesis. While AMPK is considered anti-carcinogenic, HIF1 is a pivotal factor in ensuring tumor survival and initiation of 
the Warburg effect [111]. This might be illustrated by these findings of an antagonistic regulation, especially in cancer cells, although the role of AMPK in tumorigenesis is not yet completely clear, and it might also enhance tumor survival similarly or complementary to HIF1 [5].

Beyond differences between cancer and normal cells, the effects of AMPK might generally be tissue-specific due to different metabolic profiles and needs. Majd et al. [113] reported varying time courses and intensities of AMPK activation under short-term ischemia in rat brain, liver, kidney and heart that coincide with the individual tissue sensitivities to ischemic insults. This tissue specificity might be mediated by the different combinations of AMPK subunit isoforms [8] whose specific roles remain elusive for the most part to date [114] and might mirror the metabolic specificities of different tissues. Additionally, interspecies differences have been observed [114] that will make elucidating the tissue-specific distribution and function of the different compositions of AMPK even more challenging.

Taken together, there are several pros, as well as cons, regarding a crosstalk between AMPK and HIF. Research on this topic should be intensified in order to get a better idea of the mechanisms connecting them.

Apart from classic hypoxic signaling, AMPK is linked to metabolic signaling on several levels. The AMPK/sirtuin (SIRT) 1/peroxisome proliferator-activated receptor- $\gamma$ coactivator- $1 \alpha$ (PGC-1 $\alpha$ ) axis is strongly involved in metabolic adaptation $[115,116]$ and one of the better-known connections, although its role under hypoxia has not been clarified so far. The activation of PGC- $1 \alpha$, in turn, has been shown to downregulate nuclear factor $\kappa B(N F \kappa B)[117,118]$, a transcription factor that is considered to link the immune response with the adaptation reaction to hypoxia $[119,120]$. Thus, the anti-inflammatory effect of AMPK might act as a feedback mechanism to avoid an over-activation of the immune system under cellular stress. In contrast, an activation of NFKB via TAK1, the putatively third upstream kinase of AMPK, has been described [121], also suggesting a positive relation of AMPK and NFKB activation or rather a context or tissue-dependent interplay of the various factors, fine-tuning the ideal reaction to different stressors.

\section{Conclusions}

AMPK is widely regarded to exert protective effects under hypoxia. A concerted action together with HIF would ensure cellular adaptation both in the short-term (by AMPK) and long-term (by HIF). Thus, AMPK could adapt cellular metabolism quickly after the onset of hypoxia and thus ensure cellular survival until the more sustainable adaptation mediated by HIF becomes effective. For instance, AMPK regulates transport mechanisms on the protein level that are transcriptional targets of HIF. An oxygen-dependent regulation could provide a timely activation of AMPK, so that it is activated even before cellular energy levels, and thus integrity, are affected.

This beneficial effect might be of clinical use in patients with increased risk for hypoxia-associated pathologies, like ischemic stroke or myocardial infarction, but also hypoxia-associated diseases like inflammatory bowel disease. With AMPK agonists, like the antidiabetic drug metformin, already being in clinical use their applications might easily be extended.

Altogether, there are manifold studies covering different aspects of AMPK regulation and its role and activation under hypoxia. However, the hypotheses and approaches to prove them are nearly as diverse as the number of studies. Thus, the current understanding of the regulation of AMPK activity under hypoxia is rather puzzling, and for a better understanding future studies should put special emphasis on characterizing the tissues and the tissue-specific AMPK isoforms under investigation, as well as excluding alternative pathways that might interact with the proposed mechanism.

Funding: The author acknowledges support from Leipzig University for Open Access Publishing and received a FEBS short-term fellowship during the preparation of the manuscript.

Acknowledgments: The author wants to thank E. Dimovafor enlightening discussions and most spontaneous proofreading of the manuscript as well as G. Gäbel for proofreading the manuscript.

Conflicts of Interest: The authors declare no conflict of interest. 


\section{Abbreviations}

$\begin{array}{ll}\text { AMPK } & \text { AMP-activated protein kinase } \\ \text { CaMKK } & \mathrm{Ca}^{2+} / \text { calmodulin-dependent protein kinase } \\ \text { DMOG } & \text { Dimethyloxalylglycine } \\ \text { FIH } & \text { Factor inhibiting HIF } \\ \text { HIF } & \text { Hypoxia-inducible factor } \\ \text { HIF-P4H } & \text { HIF-prolyl-4-hydroxylase } \\ \text { LKB } & \text { Liver kinase B } \\ \text { MDPI } & \text { Multidisciplinary Digital Publishing Institute } \\ \text { mTORC } & \text { Mammalian target of rapamycin complex } \\ \text { PGC-1 } \alpha & \text { Peroxisome proliferator-activated receptor- } \gamma \text { coactivator- } 1 \alpha \\ \text { ROS } & \text { Reactive oxygen species } \\ \text { SIRT } & \text { Sirtuin } \\ \text { TAK } & \text { Transforming growth factor } \beta \text {-activated kinase }\end{array}$

\section{References}

1. Hawley, S.A.; Davison, M.; Woods, A.; Davies, S.P.; Beri, R.K.; Carling, D.; Hardie, D.G. Characterization of the AMP-activated protein kinase kinase from rat liver and identification of threonine 172 as the major site at which it phosphorylates AMP-activated protein kinase. J. Biol. Chem. 1996, 271, 27879-27887. [CrossRef] [PubMed]

2. Hardie, D.G.; Ashford, M.L.J. AMPK: Regulating energy balance at the cellular and whole body levels. Physiology 2014, 29, 99-107. [CrossRef] [PubMed]

3. Hardie, D.G.; Schaffer, B.E.; Brunet, A. AMPK: An Energy-Sensing Pathway with Multiple Inputs and Outputs. Trends Cell Biol. 2016, 26, 190-201. [CrossRef] [PubMed]

4. Faubert, B.; Vincent, E.E.; Poffenberger, M.C.; Jones, R.G. The AMP-activated protein kinase (AMPK) and cancer: Many faces of a metabolic regulator. Cancer Lett. 2015, 356, 165-170. [CrossRef]

5. Salminen, A.; Kaarniranta, K.; Kauppinen, A. AMPK and HIF signaling pathways regulate both longevity and cancer growth: The good news and the bad news about survival mechanisms. Biogerontology 2016, 17, 655-680. [CrossRef]

6. Brown, E.; Taylor, C.T. Hypoxia-sensitive pathways in intestinal inflammation. J. Physiol. 2018, 596, $2985-2989$. [CrossRef]

7. Hardie, D.G.; Carling, D. The AMP-activated protein kinase-fuel gauge of the mammalian cell? Eur. J. Biochem. 1997, 246, 259-273. [CrossRef]

8. Ross, F.A.; Jensen, T.E.; Hardie, D.G. Differential regulation by AMP and ADP of AMPK complexes containing different $\gamma$ subunit isoforms. Biochem. J. 2016, 473, 189-199. [CrossRef]

9. Woods, A.; Johnstone, S.R.; Dickerson, K.; Leiper, F.C.; Fryer, L.G.D.; Neumann, D.; Schlattner, U.; Wallimann, T.; Carlson, M.; Carling, D. LKB1 is the upstream kinase in the AMP-activated protein kinase cascade. Curr. Biol. 2003, 13, 2004-2008. [CrossRef]

10. Hawley, S.A.; Pan, D.A.; Mustard, K.J.; Ross, L.; Bain, J.; Edelman, A.M.; Frenguelli, B.G.; Hardie, D.G. Calmodulin-dependent protein kinase kinase-beta is an alternative upstream kinase for AMP-activated protein kinase. Cell Metab. 2005, 2, 9-19. [CrossRef]

11. Hurley, R.L.; Anderson, K.A.; Franzone, J.M.; Kemp, B.E.; Means, A.R.; Witters, L.A. The $\mathrm{Ca}+/$ calmodulin-dependent protein kinase kinases are AMP-activated protein kinase kinases. J. Biol. Chem. 2005, 280, 29060-29066. [CrossRef] [PubMed]

12. Woods, A.; Dickerson, K.; Heath, R.; Hong, S.-P.; Momcilovic, M.; Johnstone, S.R.; Carlson, M.; Carling, D. $\mathrm{Ca} 2+/$ calmodulin-dependent protein kinase kinase-beta acts upstream of AMP-activated protein kinase in mammalian cells. Cell Metab. 2005, 2, 21-33. [CrossRef] [PubMed]

13. Xue, B.; Pulinilkunnil, T.; Murano, I.; Bence, K.K.; He, H.; Minokoshi, Y.; Asakura, K.; Lee, A.; Haj, F.; Furukawa, N.; et al. Neuronal protein tyrosine phosphatase 1B deficiency results in inhibition of hypothalamic AMPK and isoform-specific activation of AMPK in peripheral tissues. Mol. Cell. Biol. 2009, 29, 4563-4573. [CrossRef] [PubMed] 
14. Carling, D.; Sanders, M.J.; Woods, A. The regulation of AMP-activated protein kinase by upstream kinases. Int. J. Obes. 2008, 32 (Suppl. 4), S55-S59. [CrossRef]

15. Antonia, R.J.; Baldwin, A.S. IKK promotes cytokine-induced and cancer-associated AMPK activity and attenuates phenformin-induced cell death in LKB1-deficient cells. Sci. Signal. 2018, 11. [CrossRef]

16. Neumann, D. Is TAK1 a Direct Upstream Kinase of AMPK? Int. J. Mol. Sci. 2018, 19, 2412. [CrossRef]

17. Corton, J.M.; Gillespie, J.G.; Hardie, D.G. Role of the AMP-activated protein kinase in the cellular stress response. Curr. Biol. 1994, 4, 315-324. [CrossRef]

18. Lang, F.; Föller, M. Regulation of ion channels and transporters by AMP-activated kinase (AMPK). Channels 2014, 8, 20-28. [CrossRef]

19. Jornayvaz, F.R.; Shulman, G.I. Regulation of mitochondrial biogenesis. Essays Biochem. 2010, 47, 69-84.

20. Steinberg, G.R.; Kemp, B.E. AMPK in Health and Disease. Physiol. Rev. 2009, 89, 1025-1078. [CrossRef]

21. Ross, F.A.; MacKintosh, C.; Hardie, D.G. AMP-activated protein kinase: A cellular energy sensor that comes in 12 flavours. FEBS J. 2016, 283, 2987-3001. [CrossRef] [PubMed]

22. Garcia, D.; Shaw, R.J. AMPK: Mechanisms of Cellular Energy Sensing and Restoration of Metabolic Balance. Mol. Cell 2017, 66, 789-800. [CrossRef] [PubMed]

23. Ward, J.B.J.; Keely, S.J.; Keely, S.J. Oxygen in the regulation of intestinal epithelial transport. J. Physiol. 2014, 592, 2473-2489. [CrossRef] [PubMed]

24. Carreau, A.; El Hafny-Rahbi, B.; Matejuk, A.; Grillon, C.; Kieda, C. Why is the partial oxygen pressure of human tissues a crucial parameter? Small molecules and hypoxia. J. Cell. Mol. Med. 2011, 15, 1239-1253. [CrossRef] [PubMed]

25. Zeitouni, N.E.; Chotikatum, S.; von Köckritz-Blickwede, M.; Naim, H.Y. The impact of hypoxia on intestinal epithelial cell functions: Consequences for invasion by bacterial pathogens. Mol. Cell. Pediatr. 2016, 3, 14. [CrossRef] [PubMed]

26. Russell, R.R.; Li, J.; Coven, D.L.; Pypaert, M.; Zechner, C.; Palmeri, M.; Giordano, F.J.; Mu, J.; Birnbaum, M.J.; Young, L.H. AMP-activated protein kinase mediates ischemic glucose uptake and prevents postischemic cardiac dysfunction, apoptosis, and injury. J. Clin. Investig. 2004, 114, 495-503. [CrossRef]

27. Seo-Mayer, P.W.; Thulin, G.; Zhang, L.; Alves, D.S.; Ardito, T.; Kashgarian, M.; Caplan, M.J. Preactivation of AMPK by metformin may ameliorate the epithelial cell damage caused by renal ischemia. Am. J. Physiol. Ren. Physiol. 2011, 301, F1346-F1357. [CrossRef]

28. Cai, C.-C.; Zhu, J.-H.; Ye, L.-X.; Dai, Y.-Y.; Fang, M.-C.; Hu, Y.-Y.; Pan, S.-L.; Chen, S.; Li, P.-J.; Fu, X.-Q.; et al. Glycine Protects against Hypoxic-Ischemic Brain Injury by Regulating Mitochondria-Mediated Autophagy via the AMPK Pathway. Oxid. Med. Cell. Longev. 2019, 2019, 4248529. [CrossRef]

29. Hu, H.; Li, X.; Ren, D.; Tan, Y.; Chen, J.; Yang, L.; Chen, R.; Li, J.; Zhu, P. The cardioprotective effects of carvedilol on ischemia and reperfusion injury by AMPK signaling pathway. Biomed. Pharmacother. 2019, 117, 109106. [CrossRef]

30. Michiels, C. Physiological and pathological responses to hypoxia. Am. J. Pathol. 2004, 164, 1875-1882. [CrossRef]

31. Kondo, Y.; Sueyoshi, K.; Zhang, J.; Bao, Y.; Li, X.; Fakhari, M.; Slubowski, C.J.; Bahrami, S.; Ledderose, C.; Junger, W.G. Adenosine 5'-Monophosphate Protects From Hypoxia By Lowering Mitochondrial Metabolism and Oxygen Demand. Shock 2019. [CrossRef] [PubMed]

32. Rousset, C.I.; Leiper, F.C.; Kichev, A.; Gressens, P.; Carling, D.; Hagberg, H.; Thornton, C. A dual role for AMP-activated protein kinase (AMPK) during neonatal hypoxic-ischaemic brain injury in mice. J. Neurochem. 2015, 133, 242-252. [CrossRef] [PubMed]

33. Park, S.Y.; Choi, Y.-W.; Park, G. Nrf2-mediated neuroprotection against oxygen-glucose deprivation/reperfusion injury by emodin via AMPK-dependent inhibition of GSK-3ß. J. Pharm. Pharmacol. 2018, 70, 525-535. [CrossRef] [PubMed]

34. Wen, J.; Xu, B.; Sun, Y.; Lian, M.; Li, Y.; Lin, Y.; Chen, D.; Diao, Y.; Almoiliqy, M.; Wang, L. Paeoniflorin protects against intestinal ischemia/reperfusion by activating LKB1/AMPK and promoting autophagy. Pharmacol. Res. 2019, 146, 104308. [CrossRef]

35. Mulligan, J.D.; Gonzalez, A.A.; Kumar, R.; Davis, A.J.; Saupe, K.W. Aging elevates basal adenosine monophosphate-activated protein kinase (AMPK) activity and eliminates hypoxic activation of AMPK in mouse liver. J. Gerontol. A Biol. Sci. Med. Sci. 2005, 60, 21-27. [CrossRef] 
36. Mu, J.; Brozinick, J.T.; Valladares, O.; Bucan, M.; Birnbaum, M.J. A Role for AMP-Activated Protein Kinase in Contraction- and Hypoxia-Regulated Glucose Transport in Skeletal Muscle. Mol. Cell 2001, 7, 1085-1094. [CrossRef]

37. Sun, S.; Gu, Z.; Fu, H.; Zhu, J.; Ge, X.; Wu, X. Hypoxia Induces Changes in AMP-Activated Protein Kinase Activity and Energy Metabolism in Muscle Tissue of the Oriental River Prawn Macrobrachium nipponense. Front. Physiol. 2018, 9, 751. [CrossRef]

38. Siques, P.; Brito, J.; Flores, K.; Ordenes, S.; Arriaza, K.; Pena, E.; León-Velarde, F.; López de Pablo, Á.L.; Gonzalez, M.C.; Arribas, S. Long-Term Chronic Intermittent Hypobaric Hypoxia Induces Glucose Transporter (GLUT4) Translocation Through AMP-Activated Protein Kinase (AMPK) in the Soleus Muscle in Lean Rats. Front. Physiol. 2018, 9, 799. [CrossRef]

39. Marsin, A.-S.; Bertrand, L.; Rider, M.H.; Deprez, J.; Beauloye, C.; Vincent, M.F.; van den Berghe, G.; Carling, D.; Hue, L. Phosphorylation and activation of heart PFK-2 by AMPK has a role in the stimulation of glycolysis during ischaemia. Curr. Biol. 2000, 10, 1247-1255. [CrossRef]

40. Zhang, C.-S.; Hawley, S.A.; Zong, Y.; Li, M.; Wang, Z.; Gray, A.; Ma, T.; Cui, J.; Feng, J.-W.; Zhu, M.; et al. Fructose-1,6-bisphosphate and aldolase mediate glucose sensing by AMPK. Nature 2017, 548, 112-116. [CrossRef]

41. Gusarova, G.A.; Trejo, H.E.; Dada, L.A.; Briva, A.; Welch, L.C.; Hamanaka, R.B.; Mutlu, G.M.; Chandel, N.S.; Prakriya, M.; Sznajder, J.I. Hypoxia leads to $\mathrm{Na}, \mathrm{K}-\mathrm{ATPase}$ downregulation via $\mathrm{Ca}(2+)$ release-activated $\mathrm{Ca}(2+)$ channels and AMPK activation. Mol. Cell. Biol. 2011, 31, 3546-3556. [CrossRef] [PubMed]

42. Tan, C.D.; Smolenski, R.T.; Harhun, M.I.; Patel, H.K.; Ahmed, S.G.; Wanisch, K.; Yáñez-Muñoz, R.J.; Baines, D.L. AMP-activated protein kinase (AMPK)-dependent and -independent pathways regulate hypoxic inhibition of transepithelial Na+ transport across human airway epithelial cells. Br. J. Pharmacol. 2012, 167, 368-382. [CrossRef] [PubMed]

43. Dengler, F.; Rackwitz, R.; Pfannkuche, H.; Gäbel, G. Glucose transport across lagomorph jejunum epithelium is modulated by AMP-activated protein kinase under hypoxia. J. Appl. Physiol. 2017, 123, 1487-1500. [CrossRef] [PubMed]

44. Dengler, F.; Gäbel, G. The Fast Lane of Hypoxic Adaptation: Glucose Transport Is Modulated via A HIF-Hydroxylase-AMPK-Axis in Jejunum Epithelium. Int. J. Mol. Sci. 2019, 20, 4993. [CrossRef]

45. Hashimoto, T.; Murata, Y.; Urushihara, Y.; Shiga, S.; Takeda, K.; Hosoi, Y. Severe hypoxia increases expression of ATM and DNA-PKcs and it increases their activities through Src and AMPK signaling pathways. Biochem. Biophys. Res. Commun. 2018, 505, 13-19. [CrossRef]

46. De Theije, C.C.; Schols, A.M.W.J.; Lamers, W.H.; Neumann, D.; Köhler, S.E.; Langen, R.C.J. Hypoxia impairs adaptation of skeletal muscle protein turnover- and AMPK signaling during fasting-induced muscle atrophy. PLoS ONE 2018, 13, e0203630. [CrossRef]

47. Wilson, D.F.; Matschinsky, F.M. Hyperbaric oxygen toxicity in brain: A case of hyperoxia induced hypoglycemic brain syndrome. Med. Hypotheses 2019, 132, 109375. [CrossRef]

48. Kim, J.; Kundu, M.; Viollet, B.; Guan, K.-L. AMPK and mTOR regulate autophagy through direct phosphorylation of Ulk1. Nat. Cell Biol. 2011, 13, 132-141. [CrossRef]

49. Chi, Y.; Shi, C.; Zhao, Y.; Guo, C. Forkhead box O (FOXO) 3 modulates hypoxia-induced autophagy through AMPK signalling pathway in cardiomyocytes. Biosci. Rep. 2016, 36, e00345. [CrossRef]

50. Gui, D.; Cui, Z.; Zhang, L.; Yu, C.; Yao, D.; Xu, M.; Chen, M.; Wu, P.; Li, G.; Wang, L.; et al. Salidroside attenuates hypoxia-induced pulmonary arterial smooth muscle cell proliferation and apoptosis resistance by upregulating autophagy through the AMPK-mTOR-ULK1 pathway. BMC Pulm. Med. 2017, 17, 191. [CrossRef]

51. Seok, J.-Y.; Jeong, Y.-J.; Hwang, S.-K.; Kim, C.-H.; Magae, J.; Chang, Y.-C. Upregulation of AMPK by 4-O-methylascochlorin promotes autophagy via the HIF-1 $\alpha$ expression. J. Cell. Mol. Med. 2018, 22, 6345-6356. [CrossRef] [PubMed]

52. Galluzzi, L.; Pietrocola, F.; Levine, B.; Kroemer, G. Metabolic control of autophagy. Cell 2014, 159, $1263-1276$. [CrossRef] [PubMed]

53. Choi, H.; Merceron, C.; Mangiavini, L.; Seifert, E.L.; Schipani, E.; Shapiro, I.M.; Risbud, M.V. Hypoxia promotes noncanonical autophagy in nucleus pulposus cells independent of MTOR and HIF1A signaling. Autophagy 2016, 12, 1631-1646. [CrossRef] [PubMed] 
54. Chaachouay, H.; Fehrenbacher, B.; Toulany, M.; Schaller, M.; Multhoff, G.; Rodemann, H.P. AMPK-independent autophagy promotes radioresistance of human tumor cells under clinical relevant hypoxia in vitro. Radiother. Oncol. 2015, 116, 409-416. [CrossRef] [PubMed]

55. Mungai, P.T.; Waypa, G.B.; Jairaman, A.; Prakriya, M.; Dokic, D.; Ball, M.K.; Schumacker, P.T. Hypoxia triggers AMPK activation through reactive oxygen species-mediated activation of calcium release-activated calcium channels. Mol. Cell. Biol. 2011, 31, 3531-3545. [CrossRef]

56. Zhang, H.; Guan, M.; Townsend, K.L.; Huang, T.L.; An, D.; Yan, X.; Xue, R.; Schulz, T.J.; Winnay, J.; Mori, M.; et al. MicroRNA-455 regulates brown adipogenesis via a novel HIF1an-AMPK-PGC1 $\alpha$ signaling network. EMBO Rep. 2015, 16, 1378-1393. [CrossRef]

57. Moral-Sanz, J.; Lewis, S.A.; MacMillan, S.; Ross, F.A.; Thomson, A.; Viollet, B.; Foretz, M.; Moran, C.; Hardie, D.G.; Evans, A.M. The LKB1-AMPK- $\alpha 1$ signaling pathway triggers hypoxic pulmonary vasoconstriction downstream of mitochondria. Sci. Signal. 2018, 11. [CrossRef]

58. Hardie, D.G.; Ross, F.A.; Hawley, S.A. AMPK: A nutrient and energy sensor that maintains energy homeostasis. Nat. Rev. Mol. Cell Biol. 2012, 13, 251-262. [CrossRef]

59. Stahmann, N.; Woods, A.; Carling, D.; Heller, R. Thrombin activates AMP-activated protein kinase in endothelial cells via a pathway involving Ca2+/calmodulin-dependent protein kinase kinase beta. Mol. Cell. Biol. 2006, 26, 5933-5945. [CrossRef]

60. Zmijewski, J.W.; Banerjee, S.; Bae, H.; Friggeri, A.; Lazarowski, E.R.; Abraham, E. Exposure to hydrogen peroxide induces oxidation and activation of AMP-activated protein kinase. J. Biol. Chem. 2010, 285, 33154-33164. [CrossRef]

61. Evans, A.M.; Mustard, K.J.W.; Wyatt, C.N.; Dipp, M.; Kinnear, N.P.; Hardie, D.G. Does AMP-activated protein kinase couple inhibition of mitochondrial oxidative phosphorylation by hypoxia to pulmonary artery constriction? Adv. Exp. Med. Biol. 2006, 580, 147-154. [CrossRef] [PubMed]

62. Sakamoto, K.; Zarrinpashneh, E.; Budas, G.R.; Pouleur, A.-C.; Dutta, A.; Prescott, A.R.; Vanoverschelde, J.-L.; Ashworth, A.; Jovanović, A.; Alessi, D.R.; et al. Deficiency of LKB1 in heart prevents ischemia-mediated activation of AMPKalpha2 but not AMPKalpha1. Am. J. Physiol. Endocrinol. Metab. 2006, 290, E780-E788. [CrossRef] [PubMed]

63. Wyatt, C.N.; Mustard, K.J.; Pearson, S.A.; Dallas, M.L.; Atkinson, L.; Kumar, P.; Peers, C.; Hardie, D.G.; Evans, A.M. AMP-activated protein kinase mediates carotid body excitation by hypoxia. J. Biol. Chem. 2007, 282, 8092-8098. [CrossRef] [PubMed]

64. Thomas, A.; Belaidi, E.; Moulin, S.; Horman, S.; van der Zon, G.C.; Viollet, B.; Levy, P.; Bertrand, L.; Pepin, J.-L.; Godin-Ribuot, D.; et al. Chronic Intermittent Hypoxia Impairs Insulin Sensitivity but Improves Whole-Body Glucose Tolerance by Activating Skeletal Muscle AMPK. Diabetes 2017, 66, 2942-2951. [CrossRef] [PubMed]

65. Aley, P.K.; Porter, K.E.; Boyle, J.P.; Kemp, P.J.; Peers, C. Hypoxic modulation of Ca2+ signaling in human venous endothelial cells. Multiple roles for reactive oxygen species. J. Biol. Chem. 2005, 280, 13349-13354. [CrossRef] [PubMed]

66. Choi, Y.K.; Park, J.H.; Yun, J.-A.; Cha, J.-H.; Kim, Y.; Won, M.-H.; Kim, K.-W.; Ha, K.-S.; Kwon, Y.-G.; Kim, Y.-M. Heme oxygenase metabolites improve astrocytic mitochondrial function via a Ca2+-dependent HIF- $1 \alpha /$ ERR $\alpha$ circuit. PLoS ONE 2018, 13, e0202039. [CrossRef]

67. Sallé-Lefort, S.; Miard, S.; Nolin, M.-A.; Boivin, L.; Paré, M.-È.; Debigaré, R.; Picard, F. Hypoxia upregulates Malat1 expression through a CaMKK/AMPK/HIF-1 $\alpha$ axis. Int. J. Oncol. 2016, 49, 1731-1736. [CrossRef]

68. D'Autréaux, B.; Toledano, M.B. ROS as signalling molecules: Mechanisms that generate specificity in ROS homeostasis. Nat. Rev. Mol. Cell Biol. 2007, 8, 813-824. [CrossRef]

69. Fuhrmann, D.C.; Brüne, B. Mitochondrial composition and function under the control of hypoxia. Redox Biol. 2017, 12, 208-215. [CrossRef]

70. Smith, K.A.; Waypa, G.B.; Schumacker, P.T. Redox signaling during hypoxia in mammalian cells. Redox Biol. 2017, 13, 228-234. [CrossRef]

71. Emerling, B.M.; Weinberg, F.; Snyder, C.; Burgess, Z.; Mutlu, G.M.; Viollet, B.; Budinger, G.R.S.; Chandel, N.S. Hypoxic activation of AMPK is dependent on mitochondrial ROS but independent of an increase in AMP/ATP ratio. Free Radic. Biol. Med. 2009, 46, 1386-1391. [CrossRef] [PubMed]

72. Jeon, S.-M. Regulation and function of AMPK in physiology and diseases. Exp. Mol. Med. 2016, 48, e245. [CrossRef] [PubMed] 
73. Hinchy, E.C.; Gruszczyk, A.V.; Willows, R.; Navaratnam, N.; Hall, A.R.; Bates, G.; Bright, T.P.; Krieg, T.; Carling, D.; Murphy, M.P. Mitochondria-derived ROS activate AMP-activated protein kinase (AMPK) indirectly. J. Biol. Chem. 2018, 293, 17208-17217. [CrossRef] [PubMed]

74. Choi, S.L.; Kim, S.J.; Lee, K.T.; Kim, J.; Mu, J.; Birnbaum, M.J.; Soo Kim, S.; Ha, J. The regulation of AMP-activated protein kinase by $\mathrm{H}(2) \mathrm{O}(2)$. Biochem. Biophys. Res. Commun. 2001, 287, 92-97. [CrossRef]

75. Gusarova, G.A.; Dada, L.A.; Kelly, A.M.; Brodie, C.; Witters, L.A.; Chandel, N.S.; Sznajder, J.I. Alpha1-AMP-activated protein kinase regulates hypoxia-induced $\mathrm{Na}, \mathrm{K}$-ATPase endocytosis via direct phosphorylation of protein kinase C zeta. Mol. Cell. Biol. 2009, 29, 3455-3464. [CrossRef]

76. Vadász, I.; Dada, L.A.; Briva, A.; Trejo, H.E.; Welch, L.C.; Chen, J.; Tóth, P.T.; Lecuona, E.; Witters, L.A.; Schumacker, P.T.; et al. AMP-activated protein kinase regulates $\mathrm{CO}_{2}$-induced alveolar epithelial dysfunction in rats and human cells by promoting Na,K-ATPase endocytosis. J. Clin. Investig. 2008, 118, 752-762. [CrossRef]

77. Zhao, Y.; Hu, X.; Liu, Y.; Dong, S.; Wen, Z.; He, W.; Zhang, S.; Huang, Q.; Shi, M. ROS signaling under metabolic stress: Cross-talk between AMPK and AKT pathway. Mol. Cancer 2017, 16, 79. [CrossRef]

78. Wu, N.; Zheng, B.; Shaywitz, A.; Dagon, Y.; Tower, C.; Bellinger, G.; Shen, C.-H.; Wen, J.; Asara, J.; McGraw, T.E.; et al. AMPK-dependent degradation of TXNIP upon energy stress leads to enhanced glucose uptake via GLUT1. Mol. Cell 2013, 49, 1167-1175. [CrossRef]

79. Semenza, G.L. Hypoxia-inducible factor 1: Master regulator of O2 homeostasis. Curr. Opin. Genet. Dev. 1998, 8, 588-594. [CrossRef]

80. Semenza, G.L. Hydroxylation of HIF-1: Oxygen sensing at the molecular level. Physiology 2004, 19, $176-182$. [CrossRef]

81. Fandrey, J.; Schödel, J.; Eckardt, K.-U.; Katschinski, D.M.; Wenger, R.H. Now a Nobel gas: Oxygen. Pflugers Arch. 2019, 471, 1343-1358. [CrossRef] [PubMed]

82. Semenza, G.L. Oxygen sensing, hypoxia-inducible factors, and disease pathophysiology. Annu. Rev. Pathol. 2014, 9, 47-71. [CrossRef] [PubMed]

83. Schofield, C.J.; Ratcliffe, P.J. Signalling hypoxia by HIF hydroxylases. Biochem. Biophys. Res. Commun. 2005, 338, 617-626. [CrossRef] [PubMed]

84. Yan, H.; Zhang, D.-X.; Shi, X.; Zhang, Q.; Huang, Y.-S. Activation of the prolyl-hydroxylase oxygen-sensing signal cascade leads to AMPK activation in cardiomyocytes. J. Cell. Mol. Med. 2012, 16, 2049-2059. [CrossRef] [PubMed]

85. Cockman, M.E.; Lippl, K.; Tian, Y.-M.; Pegg, H.B.; Figg, W.D.; Abboud, M.I.; Heilig, R.; Fischer, R.; Myllyharju, J.; Schofield, C.J.; et al. Lack of activity of recombinant HIF prolyl hydroxylases (PHDs) on reported non-HIF substrates. Elife 2019, 8. [CrossRef]

86. Scholz, C.C.; Rodriguez, J.; Pickel, C.; Burr, S.; Fabrizio, J.-A.; Nolan, K.A.; Spielmann, P.; Cavadas, M.A.S.; Crifo, B.; Halligan, D.N.; et al. FIH Regulates Cellular Metabolism through Hydroxylation of the Deubiquitinase OTUB1. PLoS Biol. 2016, 14, e1002347. [CrossRef]

87. Huang, J.; Liu, W.; Doycheva, D.M.; Gamdzyk, M.; Lu, W.; Tang, J.; Zhang, J.H. Ghrelin attenuates oxidative stress and neuronal apoptosis via GHSR-1 $\alpha /$ AMPK/Sirt1/PGC-1 $\alpha / \mathrm{UCP} 2$ pathway in a rat model of neonatal HIE. Free Radic. Biol. Med. 2019, 141, 322-337. [CrossRef]

88. Chen, Y.; Wang, H.; Zhang, Y.; Wang, Z.; Liu, S.; Cui, L. Pretreatment of ghrelin protects H9c2 cells against hypoxia/reoxygenation-induced cell death via PI3K/AKT and AMPK pathways. Artif. Cells Nanomed. Biotechnol. 2019, 47, 2179-2187. [CrossRef]

89. Wang, B.; Cheng, K.K.-Y. Hypothalamic AMPK as a Mediator of Hormonal Regulation of Energy Balance. Int. J. Mol. Sci. 2018, 19, 3552. [CrossRef]

90. Birnbaum, M.J. Activating AMP-activated protein kinase without AMP. Mol. Cell 2005, 19, 289-290. [CrossRef]

91. Lim, C.T.; Kola, B.; Korbonits, M. AMPK as a mediator of hormonal signalling. J. Mol. Endocrinol. 2010, 44, 87-97. [CrossRef] [PubMed]

92. Minokoshi, Y.; Kim, Y.-B.; Peroni, O.D.; Fryer, L.G.D.; Müller, C.; Carling, D.; Kahn, B.B. Leptin stimulates fatty-acid oxidation by activating AMP-activated protein kinase. Nature 2002, 415, 339-343. [CrossRef] [PubMed]

93. Ma, Y.; Wang, J.; Gao, J.; Yang, H.; Wang, Y.; Manithody, C.; Li, J.; Rezaie, A.R. Antithrombin up-regulates AMP-activated protein kinase signalling during myocardial ischaemia/reperfusion injury. Thromb. Haemost. 2015, 113, 338-349. [CrossRef] [PubMed] 
94. Lin, S.-C.; Hardie, D.G. AMPK: Sensing Glucose as well as Cellular Energy Status. Cell Metab. 2018, 27, 299-313. [CrossRef] [PubMed]

95. Zhang, Y.-L.; Guo, H.; Zhang, C.-S.; Lin, S.-Y.; Yin, Z.; Peng, Y.; Luo, H.; Shi, Y.; Lian, G.; Zhang, C.; et al. AMP as a low-energy charge signal autonomously initiates assembly of AXIN-AMPK-LKB1 complex for AMPK activation. Cell Metab. 2013, 18, 546-555. [CrossRef]

96. Hay, N.; Sonenberg, N. Upstream and downstream of mTOR. Genes Dev. 2004, 18, 1926-1945. [CrossRef]

97. Gwinn, D.M.; Shackelford, D.B.; Egan, D.F.; Mihaylova, M.M.; Mery, A.; Vasquez, D.S.; Turk, B.E.; Shaw, R.J. AMPK phosphorylation of raptor mediates a metabolic checkpoint. Mol. Cell 2008, 30, 214-226. [CrossRef]

98. Brugarolas, J.; Lei, K.; Hurley, R.L.; Manning, B.D.; Reiling, J.H.; Hafen, E.; Witters, L.A.; Ellisen, L.W.; Kaelin, W.G. Regulation of mTOR function in response to hypoxia by REDD1 and the TSC1/TSC2 tumor suppressor complex. Genes Dev. 2004, 18, 2893-2904. [CrossRef]

99. Kles, K.A.; Tappenden, K.A. Hypoxia differentially regulates nutrient transport in rat jejunum regardless of luminal nutrient present. Am. J. Physiol. Gastrointest. Liver Physiol. 2002, 283, G1336-G1342. [CrossRef]

100. Chandel, N.S.; McClintock, D.S.; Feliciano, C.E.; Wood, T.M.; Melendez, J.A.; Rodriguez, A.M.; Schumacker, P.T. Reactive oxygen species generated at mitochondrial complex III stabilize hypoxia-inducible factor-1alpha during hypoxia: A mechanism of $\mathrm{O}_{2}$ sensing. J. Biol. Chem. 2000, 275, 25130-25138. [CrossRef]

101. Guzy, R.D.; Schumacker, P.T. Oxygen sensing by mitochondria at complex III: The paradox of increased reactive oxygen species during hypoxia. Exp. Physiol. 2006, 91, 807-819. [CrossRef] [PubMed]

102. Wheaton, W.W.; Chandel, N.S. Hypoxia. 2. Hypoxia regulates cellular metabolism. Am. J. Physiol. Cell Physiol. 2011, 300, C385-C393. [CrossRef] [PubMed]

103. Abdel Malik, R.; Zippel, N.; Frömel, T.; Heidler, J.; Zukunft, S.; Walzog, B.; Ansari, N.; Pampaloni, F.; Wingert, S.; Rieger, M.A.; et al. AMP-Activated Protein Kinase $\alpha 2$ in Neutrophils Regulates Vascular Repair via Hypoxia-Inducible Factor- $1 \alpha$ and a Network of Proteins Affecting Metabolism and Apoptosis. Circ. Res. 2017, 120, 99-109. [CrossRef] [PubMed]

104. Jung, S.-N.; Yang, W.K.; Kim, J.; Kim, H.S.; Kim, E.J.; Yun, H.; Park, H.; Kim, S.S.; Choe, W.; Kang, I.; et al. Reactive oxygen species stabilize hypoxia-inducible factor-1 alpha protein and stimulate transcriptional activity via AMP-activated protein kinase in DU145 human prostate cancer cells. Carcinogenesis 2008, 29, 713-721. [CrossRef]

105. Minet, E.; Michel, G.; Mottet, D.; Raes, M.; Michiels, C. Transduction pathways involved in Hypoxia-Inducible Factor-1 phosphorylation and activation. Free Radic. Biol. Med. 2001, 31, 847-855. [CrossRef]

106. Kietzmann, T.; Mennerich, D.; Dimova, E.Y. Hypoxia-Inducible Factors (HIFs) and Phosphorylation: Impact on Stability, Localization, and Transactivity. Front. Cell Dev. Biol. 2016, 4, 11. [CrossRef]

107. Laderoute, K.R.; Amin, K.; Calaoagan, J.M.; Knapp, M.; Le, T.; Orduna, J.; Foretz, M.; Viollet, B. 5'-AMP-activated protein kinase (AMPK) is induced by low-oxygen and glucose deprivation conditions found in solid-tumor microenvironments. Mol. Cell. Biol. 2006, 26, 5336-5347. [CrossRef]

108. Fukuyama, Y.; Ohta, K.; Okoshi, R.; Suehara, M.; Kizaki, H.; Nakagawa, K. Hypoxia induces expression and activation of AMPK in rat dental pulp cells. J. Dent. Res. 2007, 86, 903-907. [CrossRef]

109. Faubert, B.; Boily, G.; Izreig, S.; Griss, T.; Samborska, B.; Dong, Z.; Dupuy, F.; Chambers, C.; Fuerth, B.J.; Viollet, B.; et al. AMPK is a negative regulator of the Warburg effect and suppresses tumor growth in vivo. Cell Metab. 2013, 17, 113-124. [CrossRef]

110. Lyu, X.; Wang, J.; Guo, X.; Wu, G.; Jiao, Y.; Faleti, O.D.; Liu, P.; Liu, T.; Long, Y.; Chong, T.; et al. EBV-miR-BART1-5P activates AMPK/mTOR/HIF1 pathway via a PTEN independent manner to promote glycolysis and angiogenesis in nasopharyngeal carcinoma. PLoS Pathog. 2018, 14, e1007484. [CrossRef]

111. Zadra, G.; Batista, J.L.; Loda, M. Dissecting the Dual Role of AMPK in Cancer: From Experimental to Human Studies. Mol. Cancer Res. 2015, 13, 1059-1072. [CrossRef] [PubMed]

112. Seo, K.; Seo, S.; Ki, S.H.; Shin, S.M. Sestrin2 inhibits hypoxia-inducible factor-1 $\alpha$ accumulation via AMPK-mediated prolyl hydroxylase regulation. Free Radic. Biol. Med. 2016, 101, 511-523. [CrossRef] [PubMed]

113. Majd, S.; Power, J.H.T.; Chataway, T.K.; Grantham, H.J.M. A comparison of LKB1/AMPK/mTOR metabolic axis response to global ischaemia in brain, heart, liver and kidney in a rat model of cardiac arrest. BMC Cell Biol. 2018, 19, 7. [CrossRef] [PubMed] 
114. Wu, J.; Puppala, D.; Feng, X.; Monetti, M.; Lapworth, A.L.; Geoghegan, K.F. Chemoproteomic analysis of intertissue and interspecies isoform diversity of AMP-activated protein kinase (AMPK). J. Biol. Chem. 2013, 288, 35904-35912. [CrossRef]

115. Cantó, C.; Auwerx, J. PGC-1alpha, SIRT1 and AMPK, an energy sensing network that controls energy expenditure. Curr. Opin. Lipidol. 2009, 20, 98-105. [CrossRef]

116. Ruderman, N.B.; Xu, X.J.; Nelson, L.; Cacicedo, J.M.; Saha, A.K.; Lan, F.; Ido, Y. AMPK and SIRT1: A long-standing partnership? Am. J. Physiol. Endocrinol. Metab. 2010, 298, E751-E760. [CrossRef]

117. Salminen, A.; Hyttinen, J.M.T.; Kaarniranta, K. AMP-activated protein kinase inhibits NF- $\mathrm{kB}$ signaling and inflammation: Impact on healthspan and lifespan. J. Mol. Med. 2011, 89, 667-676. [CrossRef]

118. Chen, X.; Li, X.; Zhang, W.; He, J.; Xu, B.; Lei, B.; Wang, Z.; Cates, C.; Rousselle, T.; Li, J. Activation of AMPK inhibits inflammatory response during hypoxia and reoxygenation through modulating JNK-mediated NF-кB pathway. Metab. Clin. Exp. 2018, 83, 256-270. [CrossRef]

119. Rius, J.; Guma, M.; Schachtrup, C.; Akassoglou, K.; Zinkernagel, A.S.; Nizet, V.; Johnson, R.S.; Haddad, G.G.; Karin, M. NF-kappaB links innate immunity to the hypoxic response through transcriptional regulation of HIF-1alpha. Nature 2008, 453, 807-811. [CrossRef]

120. Oliver, K.M.; Taylor, C.T.; Cummins, E.P. Hypoxia. Regulation of NFkappaB signalling during inflammation: The role of hydroxylases. Arthritis Res. Ther. 2009, 11, 215. [CrossRef]

121. D'Ignazio, L.; Batie, M.; Rocha, S. Hypoxia and Inflammation in Cancer, Focus on HIF and NF-kB. Biomedicines 2017, 5, 21. [CrossRef] [PubMed]

(C) 2020 by the author. Licensee MDPI, Basel, Switzerland. This article is an open access article distributed under the terms and conditions of the Creative Commons Attribution (CC BY) license (http://creativecommons.org/licenses/by/4.0/). 